\title{
TREE OF LIFE
}

\section{INDIRA GJONI}

That what is mine

Isn't

The tree of life

Extends its branches

Far and wide

As life happens

While nappies need changing

Tears roll down chubby cheeks

And mothers find cold teas

In corners of homes

Where silence seldom visits

Wet kisses mop up

Emotional spills

That would otherwise build

Into anger grenades

Formed by

Exhausted brains

That seek

Rest and calm

As tired eyes

Resist sleep

And life's students

Need dropping off

Strong willed boys

Insist

On staying

Then on going

Early dinners

Arrive late

The chefs

Overcome

A sense
That time

Has no space

For me

To calmly negotiate

Life's meaning

In warm cups of tea

Or places where

Quarrelling voices

Do not live

And steal

Quiet moments to form

Memories

That we alter

As we beat

The drum of life

Years after

Recalling snippets of time

Through glasses

Not tainted by little fingers

Once stained with purpose

The carousel of life

Spins slowly

During these days it seems

Until suddenly it quickens

No longer focused on

When will this time pass?

But where has it gone? 